\title{
Levels of Ionotropic Glutamate and Muscarinic Receptors in Three Animal Models of Schizophrenia
}

\author{
Brian Dean ${ }^{* 1,2}$, Simone Boer ${ }^{1}$, Elizabeth Scarr $^{1,2}$, Jung Yoon Um ${ }^{4}$, Madhara Udawela ${ }^{1}$, Tom van \\ den Boom ${ }^{3}$, Ivo Reinieren ${ }^{3}$, Jackie Cilia ${ }^{5}$, Mark Hill ${ }^{5}$, Andrea Bradford ${ }^{5}$, Declan N.C. Jones ${ }^{6}$, and \\ Jane Gartlon ${ }^{5}$
}

\begin{abstract}
${ }^{I}$ The Rebecca L. Cooper Research Laboratories, The Mental Health Research Institute, Parkville, Victoria, Australia; ${ }^{2}$ The Department of Psychiatry, The University of Melbourne, Victoria, Australia; ${ }^{3}$ Department of Health and Environment Technology, Avans University, the Netherlands; ${ }^{4}$ Cardiovascular and Neuropharmacological Drugs Division, Korea Food and Drug Administration, Seoul, Korea; ${ }^{5}$ Neurosciences Centre of Excellence for Drug Discovery, GlaxoSmithKline plc, Third Avenue, Harlow, CM19 5AW, UK; ${ }^{6}$ Centre of Excellence for External Drug Discovery, GlaxoSmithKline plc, Gunnels Wood Rd., Stevenage, Hertfordshire, SG1 2NY, UK
\end{abstract}

\begin{abstract}
There are well validated rodent paradigms of schizophrenia which are based on environmental manipulation (e.g. altered rearing conditions) or drug challenges. These manipulations induce behavioural changes in rodents that are thought to involve neuronal circuitry similar to the ones that are affected by the pathophysiology of the disorder. This study has investigated whether three such rodent paradigms (isolation rearing, neonatal PCP treatment or sub-chronic PCP treatment) are associated with changes in muscarinic receptors (CHRMs) or ionotropic glutamate receptors, some of which have been reported to be altered in the CNS of subjects with schizophrenia. [ $\left.{ }^{3} \mathrm{H}\right]$ pirenzepine (CHRM1), $\left[{ }^{3} \mathrm{H}\right] 4 \mathrm{DAMP}$ (CHRM1/CHRM3), $\left[{ }^{3} \mathrm{H}\right]$ MK801 (NMDA receptors) and $\left[{ }^{3} \mathrm{H}\right]$ kainate (kainate receptors; KAR) binding were measured using in situ radioligand binding and autoradiography. Isolation rearing caused widespread decreases in $\left[{ }^{3} \mathrm{H}\right] 4 \mathrm{DAMP}(\mathrm{p}=0.01)$ and $\left[{ }^{3} \mathrm{H}\right]$ kainate binding $(\mathrm{p}=0.03)$. Neonatal PCP caused widespread increases in $\left[{ }^{3} \mathrm{H}\right] 4 \mathrm{DAMP}$ binding $(\mathrm{p}<0.0001)$, whereas sub-chronic PCP treatment caused widespread decreases in the binding of that radioligand $(\mathrm{p}<0.002)$ and widespread increases in $[3 \mathrm{H}] \mathrm{MK} 801$ binding $(\mathrm{p}<0.0001)$. There were no changes in $\left[{ }^{3} \mathrm{H}\right]$ pirenzepine binding to CHRM1 receptors in any paradigm or no significant within region changes in the binding of any radioligand. In conclusion, in the absence of any changes in CHRM1 receptors, our $\left[{ }^{3} \mathrm{H}\right] 4 \mathrm{DAMP}$ and the binding of [3H]MK801 data would suggest that different rodent paradigms cause variable changes in levels of CHRM3 and KAR in the rat CNS. Our data raises the possibility that such changes may, in part, modulate the behavioural differences that have been observed after isolation rearing, neonatal PCP treatment or sub-chronic PCP treatment.
\end{abstract}

Keywords: Neonatal PCP, chronic PCP, neonatal depravation, muscarinic receptors, NMDA, AMPA, kainate.

\section{INTRODUCTION}

Schizophrenia appears to manifest in individuals with a genetic predisposition after exposure to environmental factors which trigger the onset of the disorder [1]. This has resulted in the hypothesis that the disorder is an outcome of complex gene $\mathrm{x}$ environment interactions. Importantly, it has been noted that both pre- or peri-natal insults are associated with an increased risk of schizophrenia [2]. However, it is not clear how insults at such an early stage in human neurodevelopment can result in a disorder with a peak onset in late adolescence or early adulthood in males and with a 5 year delay in females [3]. The relatively late onset of the disorder has lead to speculation that either early life insults cause changes in neurodevelopment that do not result in functional abnormalities until late in CNS maturation or that schizophrenia results from abnormalities in late stage CNS

*Address Correspondence to this author at the Rebecca L. Cooper Research Laboratories, The Mental Health Research Institute, Locked Bag 11, Parkville, Victoria, Australia; Tel: 613-9389-2940; Fax: 613-9387-5061;

E-mail: anddali@unimelb.edu.au maturation processes [4]. Whichever hypotheses may be correct, it is now widely accepted that changes in CNS gene expression is an endpoint of the complex gene $x$ environmental interactions that underpin the onset of the symptoms of schizophrenia $[1,5]$. At the level of gene expression, there are now considerable bodies of data showing changes in levels of ionotropic glutamate receptors [6-13] and muscarinic receptors (CHRMs) [7, 14-22] in the CNS of subjects with the schizophrenia. The possibility that these changes occur because of gene $x$ environment interactions is supported by the demonstration that changing environment can affect levels of ionotropic receptors and CHRMs in the CNS of genetically modified, but not wild type, mice $[23,24]$. Given the well documented changes in ionotropic receptors and CHRMs in the CNS from subjects with schizophrenia, knowing how gene $\mathrm{x}$ environment interactions can affect the expression of these receptors would be a significant advance in understanding the pathophysiology of the disorder. In this respect, it is significant that N-methyl-D-aspartic acid (NMDA) receptor antagonists such as phencyclidine (PCP) and ketamine 
induce schizophrenia-like symptoms in humans and worsen symptoms in subjects with schizophrenia [25]. These data, along with that from other lines of research such as postmortem studies [26], underpin the hypotheses that glutamatergic pathways are involve in the pathophysiology of the disorder [27]. Subsequently, the need to better understand the role of the glutamatergic pathways in the mammalian CNS and how they may be involved in the genesis of schizophrenia lead to the study of the effects of PCP treatment in rodents [28]. Such studies have shown that the acute administration of PCP produces transient behavioural effects thought to be analogous to positive, negative and cognitive symptom domains of schizophrenia (reviewed in [29]). More recently, longer term PCP treatments (e.g. sub-chronic PCP treatment of adult rats [30] or repeated PCP treatment of neonatal rats (a single administration on post-natal days 7,9 and 11) [31] has been shown to be advantageous because such treatments produce long term behavioural changes in the absence of the overt neurodegeneration observed after high dose acute PCP treatment [32]. These differences are important because neurodegeneration does not seem to occur in the CNS of subjects with schizophrenia [33]. Moreover, repeated PCP treatment regimes cause long term robust deficits in cognitive function $[34,35]$, a heightened response to psychostimulants [36] and deficits in social behaviours [37-39] along with neuroanatomical changes such as hippocampal and cortical parvalbumin deficits [40,41], regional specific changes in N-acetylaspartate [42], reductions in spine density in pre-frontal cortex [29] and regionally specific changes in BDNF expression [43], all of which have been reported in the CNS of subjects with schizophrenia. Thus, neonatal and sub-chronic PCP treatment would appear to offer the opportunity to study the impact of a controlled environmental factor on brain development in a rodent model that appears to have relevance to schizophrenia.

Isolation rearing is a rodent paradigm that also alters behaviours such as locomotor activity, pre-pulse inhibition (PPI), responsiveness to psycho-stimulants and cognitive functioning [44, 45]. In addition, rats subjected to isolation rearing have alterations in dopamine and serotonin neurochemistry, volume loss in the prefrontal cortex, reduced $\mathrm{N}$-acetylaspartate in the temporal cortex, reduced hippocampal parvalbumin, reduced prefrontal GAT-1, increased prefrontal NR2A subunit expression, and reduced cortical and hippocampal spine density [43, 45-48], all of which have been reported as present in the CNS from subjects with schizophrenia. Importantly, a comparison of results from PCP treatment and isolation rearing suggest that different behavioural phenotypes result from each manipulation (e.g. the reproducible PPI deficit seen in isolation reared rats [45] is not a robust observation following sub-chronic or neonatal PCP administration [49, $50])$. Hence, we postulated that the study of changes in CNS molecular cytoarchitecture across rodent models could reveal different outcomes from gene $\mathrm{x}$ environment interactions on the molecular cytoarchitecture that could have relevance to changes that occur in the CNS of subjects with schizophrenia. As the initial step in testing this hypothesis we measured levels of ionotropic glutamate receptors and
CHRMs in the CNS of adult rats following either isolation rearing, neonatal or sub-chronic exposure to PCP because levels of these receptors appear to be altered in the CNS from subjects with schizophrenia.

\section{MATERIALS AND METHODS}

\section{Materials}

$\left[{ }^{3} \mathrm{H}\right]$ pirenzepine, $\left[{ }^{3} \mathrm{H}\right]$ kainic acid, $\left[{ }^{3} \mathrm{H}\right]$ dizocilpine $\left(\left[{ }^{3} \mathrm{H}\right] \mathrm{MK}\right.$ $801)$, and $\left[{ }^{3} \mathrm{H}\right] 4$-diphenylacetoxy-N-methyl-piperidine methiodide $\left({ }^{3} \mathrm{H}\right]$ 4DAMP) were sourced from Perkin Elmer. $\left[{ }^{3} \mathrm{H}\right]$ microscales were obtained from Amersham. All other laboratory grade chemicals were sourced from SigmaAldrich, Pty., Ltd. Animal Models Studies were conducted in compliance with the Home Office Guidance on the operation of the UK Animals (Scientific Procedures) Act 1986, and were approved by the GlaxoSmithKline Animal Procedures Review Panel.

\section{Isolation Reared Rats}

Male Lister Hooded rats (Charles River, UK) arrived at the facility on post-natal day (PND) 8-9 with foster mothers [11 pups per female, fostered at birth (PND 0)]. The rat pups used in the isolation rearing paradigm were cross-fostered at PND0 at the breeding facility. Cross-fostering at this age is not known to have any effect on either maternal interaction or overall development. On PND 28, the rats were rehoused singly (isolates) or in groups of five (grouped). In the case of group housing, animals were maintained in large "P2000" cages from Techniplast UK and there is no evidence that these conditions, which exceed stringent minimum requirements outlined by UK home office legislation, causes any stress to the animals. Animals raised under both conditions were housed in the same holding room for a period of 8 weeks before PPI testing. For a full description of isolation rearing and PPI procedure (see [51]; notably there was significantly impaired PPI in the animals that had undergone isolated rearing (Group housed $=61.8+/-3.1$ $\%$ PPI $v s$. Isolation reared $=5.2+/-9.2 \%$ PPI; $\mathrm{p}<0.01, \mathrm{n}=$ $10-12$,$) . Brains were collected for neurochemical analyses$ close to PND 133.

\section{Neonatal PCP-Treated Rats}

Pregnant time-mated Lister Hooded dams were obtained 7 days before parturition (Charles River, UK). In order to allow the dosing on PND7, the rat pups used in the neonatal PCP paradigm were not cross-fostered and disturbances to the litters were minimised prior to the PCP dosing starting on PND 7. Male pups were injected with PCP $(10 \mathrm{mg} / \mathrm{kg}$ s.c. $)$ on PNDs 7,9 and 11 which is a well established dosing regimen [31]. Pups were weaned on PND 21 and grown to adulthood (PND 56 onwards). As described previously [52], the motor activity response to a novel environment was shown to be increased in the PCP treated rats when measured around PND 60 (Box crossings; Vehicle $=76.1+/-3.2$, PCP $=97.3+/-5.0, \mathrm{n}=45, \mathrm{p}<0.01)$ in animals from which brains were collected for neurochemical analyses on PND 75 for this study.

\section{Sub-Chronic PCP-treated rats}

Male Lister Hooded rats (Charles River, UK), approximately $200-220 \mathrm{~g}$ at the time of dosing, were administered PCP (1 mg/kg i.p.) or vehicle (saline solution), 
twice daily (am and pm) for 7 days $[30,53]$ followed by 7 days washout. Two weeks later brains were collected for neurochemical analyses. Sub-chronic PCP-treated rats were not assessed for behavioural changes, as previous studies in our laboratory have demonstrated a heightened motor activity response to a challenge dose of PCP in every batch of animals tested $(>10)[53]$.

\section{Tissue Preparation}

In all cases, rats were killed by decapitation after stunning and without anaesthesia. Brains were rapidly frozen and stored at $-70^{\circ} \mathrm{C}$ until required. Subsequently, 25 sequential frozen sections $(20 \mu \mathrm{m}$ thick; 3 total binding, 2 non-specific binding for each radioligand) were cut, beginning approximately $4.0 \mathrm{~mm}$ posterior to Bregma.

\section{Radioligand Binding with in Situ Autoradiography}

Radioligand binding for this study was carried out using single-point saturation analyses; because the radioligand was present at concentrations at least three times that of the $\mathrm{Kd}$ for each radioligand, this approach gives a good estimate of total receptor density [54].

The binding of $\left[{ }^{3} \mathrm{H}\right]$ kainic acid and $\left[{ }^{3} \mathrm{H}\right] \mathrm{MK}-801$ [9] as well as $\left[{ }^{3} \mathrm{H}\right]$ pirenzepine [7] and $\left[{ }^{3} \mathrm{H}\right] 4 \mathrm{DAMP}[55]$ binding were measured as described previously (conditions summarised in Table 1). Following completion of the radioligand binding protocols; tissue sections were washed, dried and partially fixed prior to being opposed to BASTR2025 phospho-imaging plates with $\left[{ }^{3} \mathrm{H}\right]$ micro-scales until a quantifiable image was obtained and then scanned using a BAS5000 high resolution phosphoimager (Fuji Photo Film Co.) [56]. Images were analysed using AIS image analysis software (Imaging Research Inc.). Measurements from $\left[{ }^{3} \mathrm{H}\right]$ high micro-scales were recorded and a standard curve was generated from the values. Total binding (TB) and nonspecific binding (NSB) values were obtained by comparing the intensity of the tissue section image to the $\left[{ }^{3} \mathrm{H}\right]$ microscales based standard curve so that the radioligand binding could be calculated as d.p.m/mg ETE (Estimated Tissue Equivalent). These values were then converted to $\mathrm{fmol} / \mathrm{mg}$ ETE using the specific activities of the individual radioligands and specific binding calculated by subtracting NSB from TB.

\section{Cresyl Violet Staining}

To determine the distribution of radioligand binding, discrete areas of binding on each autoradiograph were compared to the section from which the autoradiograph was generated after the section had been stained with cresyl violet. Cresyl violet staining was performed as described previously [57] after the autoradiographic image had been generated. Thus, sections were fixed in $10 \%$ formalin in phosphate buffered saline for 1 hour at RT. Sections were immersed in $0.1 \%$ cresyl violet in $1 \%$ acetic acid for 15 minutes at $37^{\circ} \mathrm{C}$ and then rinsed in $\mathrm{dH}_{2} \mathrm{O}$. Slides were immersed for 1 minute twice in ethanol and then twice in xylene substitute for 1 minute at RT. Sections were mounted in DPX and imaged using a light microscope with a digital camera attached.

\section{Analysis}

In this study, measurements were taken based on discrete areas of radioligand binding and the cytoarchitectural regions included within these regions of binding determined. This approach minimised the number of measurements made and hence lessoned the likelihood of Type 1 errors [58]. All experimental data were interrogated with a Grubb's test to identify any statistically significant outliers, unless stated otherwise, no outlying data was found. The distribution of each data set was assessed using D'Agostino and Pearson omnibus normality and unless stated otherwise data distribution was parametric. Two-way ANOVAs, with either rearing condition or drug treatment and $\mathrm{CNS}$ regions as variables were used to identify any variance in radioligand binding. Bonferroni post-hoc tests were then used to identify the source of the variance. For transparency, where outlying data were found, statistically analyses without the outlying data are presented as the primary analyses and the analyses with the outlying data are presented within square brackets.

\section{Results}

\section{Muscarinic Receptors: [ H]Pirenzepine Binding}

Specific $\left[{ }^{3} \mathrm{H}\right]$ pirenzepine binding was apparent in the cortex, stratum oriens, stratum lacunosum, strata granulosum, molecular and the polymorphic layer of the dentate gyrus (Fig. 1A). Cortical $\left[{ }^{3} \mathrm{H}\right]$ pirenzepine binding was in three layers, Layer 1 containing cortical laminae I and II, Layer 2 containing cortical Laminae III and IV with Layer 3 containing cortical Laminae V and VI [59]. There was an outlying data point in Layer 1 and Layer 3 of one rat in the sub-chronic PCP treated rats (Table 2).

Table 1. The Conditions Used to Determine Receptor Binding in Rats that had Undergone either Experienced or not Experience Maternal Deprivation or had Neonatal or Sub-Chronic Treatment with PCP or Vehicle

\begin{tabular}{|c|c|c|c|c|}
\hline Receptor & Radioligand & Competing Compound & Buffer & Conditions \\
\hline Muscarinic M1/M4 & $15 \mathrm{nM}\left[{ }^{3} \mathrm{H}\right]$ pirenzepine & $\begin{array}{c}1 \mu \mathrm{M} \text { QNX (3-quinuclidinyl } \\
\text { xanthene-9-carboxylate hemioxalate } \\
\text { salt) }\end{array}$ & $\begin{array}{c}10 \mathrm{mM} \mathrm{KH}_{2} \mathrm{PO}_{4} \\
10 \mathrm{mMNa}_{2} \mathrm{HPO}_{4}, \mathrm{pH} 7.4\end{array}$ & $\begin{array}{l}\text { Pre-Incubation: Nil } \\
\text { Incubation: 30min, RT }\end{array}$ \\
\hline Kainate & 40nM $\left[{ }^{3} \mathrm{H}\right]$ kainic acid & 1mM L-glutamate & 50mM TRIS-Acetate (pH7.4) & $\begin{array}{l}\text { Pre-Incubation: } 30 \mathrm{~min}, 4^{\circ} \mathrm{C} \\
\text { Incubation: } 60 \mathrm{~min}, 4^{0} \mathrm{C}\end{array}$ \\
\hline NMDA & $20 \mathrm{nM}\left[{ }^{3} \mathrm{H}\right] \mathrm{MK}-801$ & $100 \mu \mathrm{M}$ MK- 801 & $\begin{array}{c}\text { 50mM TRIS-Acetate (pH7.4), } \\
100 \mu \mathrm{M} \text { glutamate, } 50 \mu \mathrm{M} \\
\text { glycine, } 50 \mu \mathrm{M} \text { spermidine }\end{array}$ & $\begin{array}{l}\text { Pre-Incubation: } 30 \mathrm{~min}, 4^{0} \mathrm{C} \\
\text { Incubation: } 60 \mathrm{~min}, \mathrm{RT}\end{array}$ \\
\hline
\end{tabular}

Abbreviations: 4DAMP $=$ 4-diphenylacetoxy-N-methyl-piperidine methiodide, NMDA = N-methyl-D-aspartate, QNX $=3$-quinuclidinyl xanthene-9-carboxylate hemioxalate salt, $\mathrm{RT}=$ room temperature. 
Table 2. The Binding (Mean \pm SEM fmol / mg Estimated Tissue Equivalents) of $\left[{ }^{3}\right.$ H]pirenzepine, $\left[{ }^{3} \mathrm{H}\right] 4 D A M P,\left[{ }^{3} \mathrm{H}\right] \mathrm{kainate}$ and $\left[^{3} \mathrm{H}\right] \mathrm{MK801}$ to the CNS from Three Paradigms that are Suggested to Precipitated Behavioural Outcomes Similar to those Displayed by Subjects with Schizophrenia

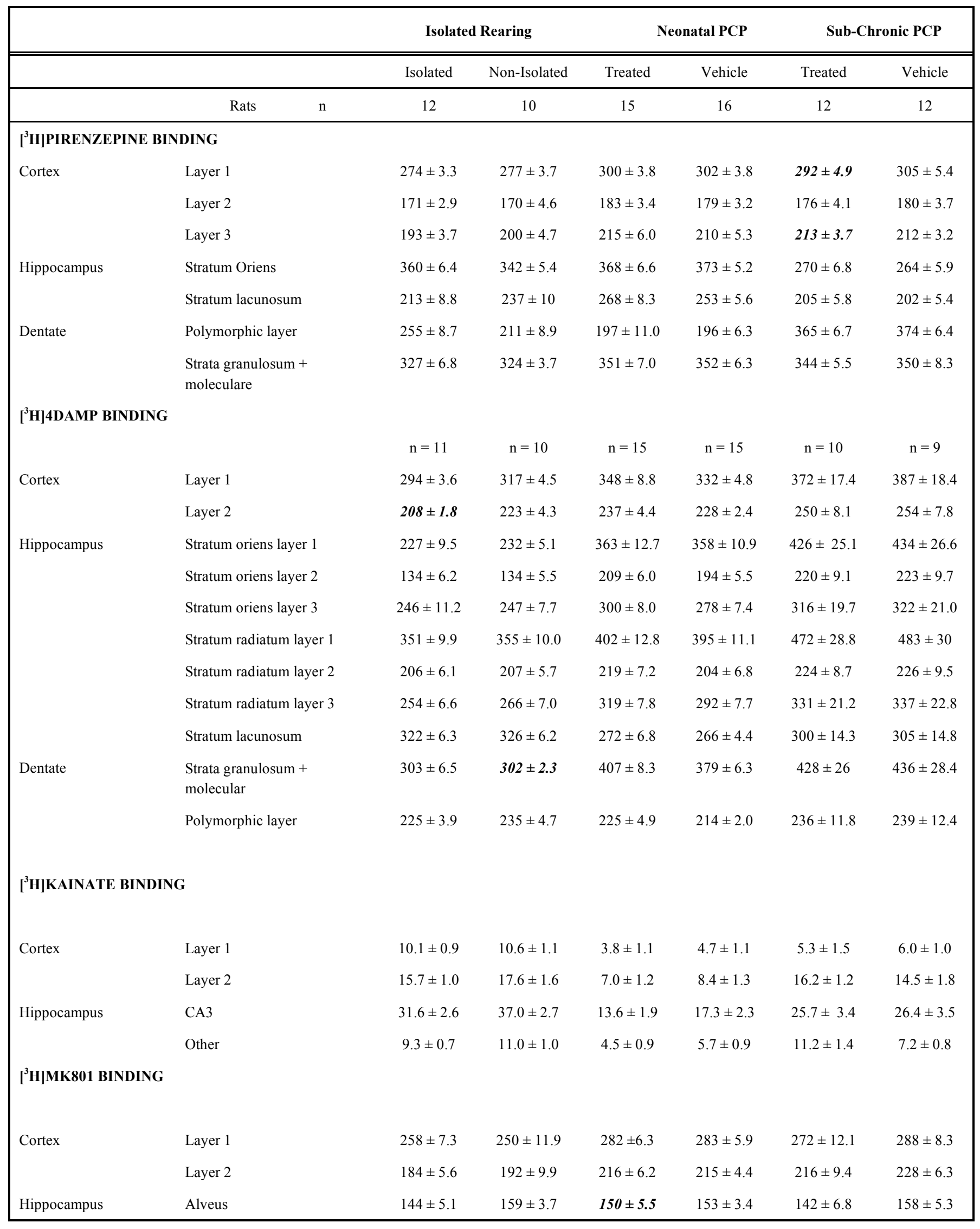


Table 2. Contd....

\begin{tabular}{|c|c|c|c|c|c|c|c|}
\hline CA1 & Stratum oriens & $402 \pm 11.3$ & $393 \pm 11.5$ & $422 \pm 13.6$ & $432 \pm 8.1$ & $396 \pm 16.3$ & $422 \pm 13.8$ \\
\hline & Stratum radiatum & $414 \pm 11.2$ & $402 \pm 10.0$ & $445 \pm 11.0$ & $452 \pm 7.8$ & $413 \pm 18.5$ & $441 \pm 16.4$ \\
\hline \multirow[t]{2}{*}{ CA2 } & Stratum oriens & $265 \pm 7.4$ & $267 \pm 5.9$ & $295 \pm 7.0$ & $303 \pm 6.7$ & $271 \pm 9.0$ & $288 \pm 9.0$ \\
\hline & Stratum radiatum & $296 \pm 7.4$ & $302 \pm 9.1$ & $340 \pm 8.8$ & $348 \pm 8.5$ & $303 \pm 11$ & $329 \pm 10.8$ \\
\hline \multirow[t]{2}{*}{ CA3 } & Stratum oriens & $308 \pm 9.5$ & $299 \pm 7.6$ & $324 \pm 9.8$ & $326 \pm 6.2$ & $296 \pm 12.4$ & $313 \pm 10.8$ \\
\hline & Stratum pyramidale & $171 \pm 5.0$ & $170 \pm 7.0$ & $188 \pm 5.1$ & $191 \pm 5.1$ & $171 \pm 8.4$ & $189 \pm 8.3$ \\
\hline Dentate & $\begin{array}{l}\text { Stratum granulosum + } \\
\text { polymorphic layer }\end{array}$ & $154 \pm 4.8$ & $157 \pm 8.2$ & $185 \pm 4.0$ & $186 \pm 4.3$ & $169 \pm 7.0$ & $189 \pm 7.8$ \\
\hline
\end{tabular}

\section{${ }^{3}$ H]Pirenzepine Binding: Isolation Reared Rats}

Isolated rearing was not associated with any significant variation in $\left[{ }^{3} \mathrm{H}\right]$ pirenzepine binding $(\mathrm{F}=1.8$, d.f. $=1,6,140$, $\mathrm{p}=0.18)$. There was a significant variation in binding between CNS regions $(\mathrm{F}=220$, d.f. $=1,6,140, \mathrm{p}<0.001)$ (Table 2). There was a significant interaction between the variables $(F=5.7$, d.f. $=1,6,140, p<0.001)$. The rank order of binding of $\left[{ }^{3} \mathrm{H}\right]$ pirenzepine across regions showed a change in rank order between polymorphic layer of the dentate gyrus and stratum lacunosum between rearing conditions due to $\left[{ }^{3} \mathrm{H}\right]$ pirenzepine binding being significantly increased $(p=0.002)$ in the polymorphic layer of the dentate gyrus and a trend to being decreased (not significant: $\mathrm{p}=$ 0.09 ) in the stratum lacunosum from the isolated reared rats (Table 2; Fig. 1B). Notably, these changes in $\left[{ }^{3} \mathrm{H}\right]$ pirenzepine binding did not survive correction for repeated measures within the two-way ANOVA.

\section{${ }^{3}$ H]Pirenzepine Binding: Neonatal PCP treated rats}

There was no significant variation in $\left[{ }^{3} \mathrm{H}\right]$ pirenzepine binding with drug treatment in the neonatal PCP treated rats $(\mathrm{F}=0.41$, d.f. $1,6,203, \mathrm{p}=0.52)$ but there was significant variation in binding between CNS regions $(\mathrm{F}=307$, d.f. $=$ $6,1,203, \mathrm{p}<0.001$ ) (Table 2). There was no interaction between the variables $(\mathrm{F}=0.59$, d.f. $=6,1,203, \mathrm{p}=0.74)$. The rank order of $\left[{ }^{3} \mathrm{H}\right]$ pirenzepine binding was the same for both the treated and vehicle group.

\section{${ }^{3}$ H/Pirenzepine Binding: Sub-Chronic PCP Treated Rats}

$\left[{ }^{3} \mathrm{H}\right]$ pirenzepine binding did not vary with sub-chronic PCP treatment $(\mathrm{F}=1.01$, d.f. $1,6,152, \mathrm{p}=0.32[\mathrm{~F}=0.63$, d.f. $1,6,154,, p=0.43]$ ) but there was significant variation in binding between CNS regions $(\mathrm{F}=298$, d.f. $=6,1,152, \mathrm{p}<$ $0.001[\mathrm{~F}=30$, d.f. $=6,1,154, \mathrm{p}<0.001]$ ) (Table 2). There was no interaction between the variables $(\mathrm{F}=0.39$, d.f. $=$ $6,1,152, p=0.89[F=0.39$, d.f. $=6,1,154, p=0.89])$. The rank order of $\left[{ }^{3} \mathrm{H}\right]$ pirenzepine binding was the same for both groups.

\section{Muscarinic Receptors: [ $\left.{ }^{3} H\right] 4 D$ AMP binding}

Specific $\left[{ }^{3} \mathrm{H}\right] 4 \mathrm{DAMP}$ binding could be measured in the cortex, stratum radiatum, dentate gyrus, stratum lacunosum and the stratum oriens (Fig. 1C). Radioligand binding in the cortex was in two layers with the outer layer of binding encompassing cortical laminae I and II with the inner layer across the remaining laminae of the cortex. Notably, the binding of $\left[{ }^{3} \mathrm{H}\right] 4 \mathrm{DAMP}$ in the stratum oriens and stratum radiatum could be divided into three discrete layers (Table 2). There was an outlying data point for the data from cortical Layer 2 from one rat in the isolated reared animals and in the strata granulosum + molecular from one of the group reared rats. To do

\section{${ }^{3}$ H]4DAMP Binding: Isolation Reared rats}

Isolated rearing was associated with a significant variation in $\left[{ }^{3} \mathrm{H}\right] 4 \mathrm{DAMP}$ binding $(\mathrm{F}=6.06$, d.f. $=1,10,207$, $\mathrm{p}=0.01[\mathrm{~F}=7.01$, d.f. $=1,10,209, \mathrm{p}=0.009])$ which also varied between CNS region $(\mathrm{F}=175$, d.f. $=1,10,207, \mathrm{p}<$ $0.0001[\mathrm{~F}=176$, d.f. $=1,10,209, \mathrm{p}<0.001])$. There was no interaction between the variables $(\mathrm{F}=0.59$, d.f. $=1,10,207, \mathrm{p}$ $=0.82[\mathrm{~F}=0.59$, d.f. $=1,10,209, \mathrm{p}=0.81])$. Further analyses failed to show any region specific changes in $\left[{ }^{3} \mathrm{H}\right] 4 \mathrm{DAMP}$ binding indicating the global variation was due to the summed effects of widespread non-significant decreases in radioligand binding in the isolated reared rats (Fig. 1D). There was no change in the rank order of $\left[{ }^{3} \mathrm{H}\right] 4 \mathrm{DAMP}$ binding between treatments.

\section{LH]4DAMP Binding: Neonatal PCP Treated Rats}

$\left[{ }^{3} \mathrm{H}\right] 4 \mathrm{DAMP}$ binding varied with PCP treatment $(\mathrm{F}=21$, d.f. $=1,10,308, \mathrm{p}<0.0001)$ and between $\mathrm{CNS}$ regions $(\mathrm{F}=$ 179 , d.f. $=1,10,308, \mathrm{p}<0.0001)$. There was no significant interaction between PCP treatment and $\mathrm{CNS}$ regions $(\mathrm{F}=$ 0.57 , d.f. $=1,10,308, p=0.83)$. Post hoc analyses failed to 
A

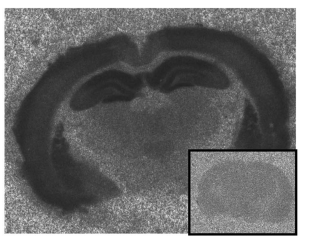

B

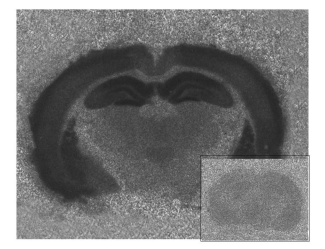

POLYMORPHIC LAYER

C DENTATE GYRUS

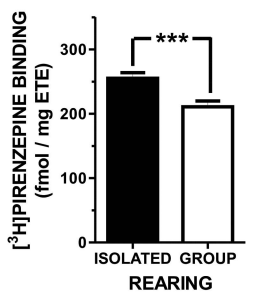

$\mathbf{E}$

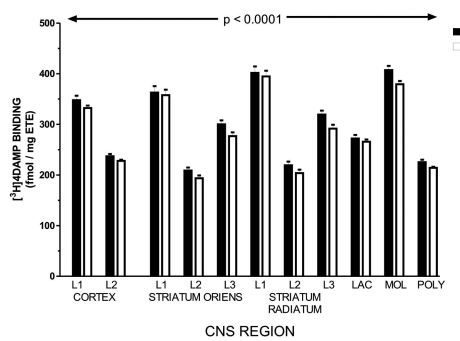

D
ISOLATED REARING

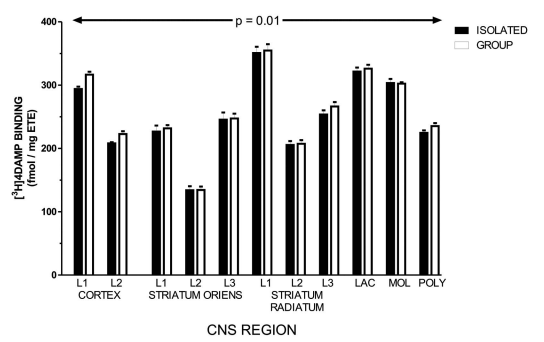

F SUB-CHRONIC PCP

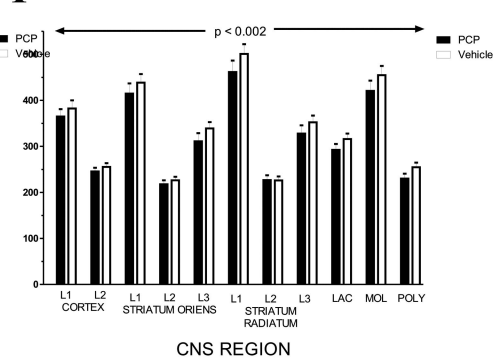

Fig. (1). A \& B: Typical autoradiographs showing the total and non-specific binding (insert) of $\left[{ }^{3} \mathrm{H}\right]$ pirenzepine (A) and $\left[{ }^{3} \mathrm{H}\right] 4 \mathrm{DAMP}(\mathrm{B})$ binding to rat CNS. C: The specific binding (mean \pm SEM) of $\left[{ }^{3} \mathrm{H}\right]$ pirenzepine to the polymorphic layer of the dentate gyrus from rats after isolated or combined rearing. D-F: The specific binding (mean \pm SEM) of $\left[{ }^{3} \mathrm{H}\right] 4 \mathrm{DAMP}$ to CNS from rats after isolated or combined rearing (D) and neonatal (E) or sub-chronic PCP treatment. $* * * p=0.002)$.

show any region specific changes in $\left[{ }^{3} \mathrm{H}\right]$ 4DAMP binding indicating the variation in radioligand binding was due to widespread non-significant increases in radioligand binding in the PCP treated rats (Fig. 1E). The was no change in the rank order of binding.

\section{I'H]4DAMP Binding: Sub-Chronic PCP Treated Rats}

$\left[{ }^{3} \mathrm{H}\right] 4$ DAMP binding varied with PCP treatment $(\mathrm{F}=10$, d.f. $=1,10,242, \mathrm{p}<0.002)$ and between CNS regions $(\mathrm{F}=68$. d.f. $=1,10,242, p<0.0001)$. There was no interaction between variance after PCP treatment $\mathrm{x}$ CNS regions $(\mathrm{F}=$ 0.28 , d.f. $=1,10,242, p=0.99$ ). Post hoc analyses failed to show any region specific changes in $[3 \mathrm{H}] 4 \mathrm{DAMP}$ binding suggesting the increased variance was due to widespread non-significant decreases in radioligand binding in the treated rats (Fig. 1F). There was no change in the rank order of binding.

\section{Ionotropic Glutamate Receptors: [ 3 H]Kainate Binding}

Specific $\left[{ }^{3} \mathrm{H}\right]$ kainate binding was measured in the cortex, the $\mathrm{CA} 3$ region of the hippocampus and as homogenous low levels of specific $\left[{ }^{3} \mathrm{H}\right]$ kainate binding across the rest of the hippocampus (Fig. 2A). There were two layers of cortical binding with Layer 1 encompassing cortical laminae I - III and Layer 2 encompassing cortical laminae IV and VI. For both the neonatal PCP and sub-chronic treatment groups the distribution of $\left[{ }^{3} \mathrm{H}\right]$ kainate binding was not binomial in the CA 3 region of the vehicle group. However, as the majority of data was normally distributed the more conservative parametric statistic was used for all analyses.

\section{$\Gamma^{3}$ HJKainate Binding: Isolation Reared Rats}

$\left[{ }^{3} \mathrm{H}\right]$ kainate binding varied with rearing $(\mathrm{F}=4.6$, d.f. $=$ $1,3,80, p=0.03)$ and between CNS regions $(F=102$, d.f. $=$
$3,1,80, \mathrm{p}<0.001)$. There was no interaction between the variables $(\mathrm{F}=0.86$, d.f. $=3,1,80, \mathrm{p}=0.46)$ (Table 2, Fig. 2C). Post hoc analyses failed to detect any significant differences in $\left[{ }^{3} \mathrm{H}\right]$ kainate binding within a CNS region (Table 2, Fig. 2C). Thus, the significant difference in global $\left[{ }^{3} \mathrm{H}\right]$ kainate binding with rearing probably results from the cumulative effect of small non-significant decrease in radioligand binding in each CNS region. The rank order of regional binding was not changed.

\section{[PH]Kainate Binding: Neonatal PCP Treated rats}

$\left[{ }^{3} \mathrm{H}\right]$ kainate binding did not vary with $\mathrm{PCP}$ treatment $(\mathrm{F}=$ 3.2 , d.f. $=1,3,116, \mathrm{p}=0.08)$ but did vary between CNS regions $(\mathrm{F}=26$, d.f. $=3,1,116, \mathrm{p}<0.0001)$ (Table 2). There was no interaction between the variables $(\mathrm{F}=0.4$, d.f. $=$ $3,1,116, p=0.75)$. The rank order of regional binding is shown in was not changed.

\section{[PH]Kainate Binding: Sub-Chronic PCP Treated Rats}

$\left[{ }^{3} \mathrm{H}\right]$ kainate binding did not vary with PCP treatment $(\mathrm{F}=$ 0.55 , d.f. $=1,3,86, p=0.46)$ but binding did vary between CNS regions $(\mathrm{F}=39$, d.f. $=3,1,86, \mathrm{p}<0.0001)$ (Table 2$)$. There was no interaction between the variables $(F=0.66$, d.f. $=3,1,86, p=0.58$ ). The rank order of regional binding was not changed..

\section{Ionotropic Glutamate Receptors: [ 3 H]MK 801 Binding}

Specific $\left[{ }^{3} \mathrm{H}\right] \mathrm{MK} 801$ binding had the highest number of discrete binding regions (Fig. 2B). Binding in the cortex was in two layers with Layer 1 encompassing cortical laminae I to III and Layer 2 encompassing cortical laminae IV to VI. In the hippocampus specific binding was measurable in the alveus, CA 1, CA2, CA3 (Strata oriens, pyramidale and radiatum in all CA regions), dentate gyrus (Stratum moleculare and polymorphic layer + Stratum granulosum) 

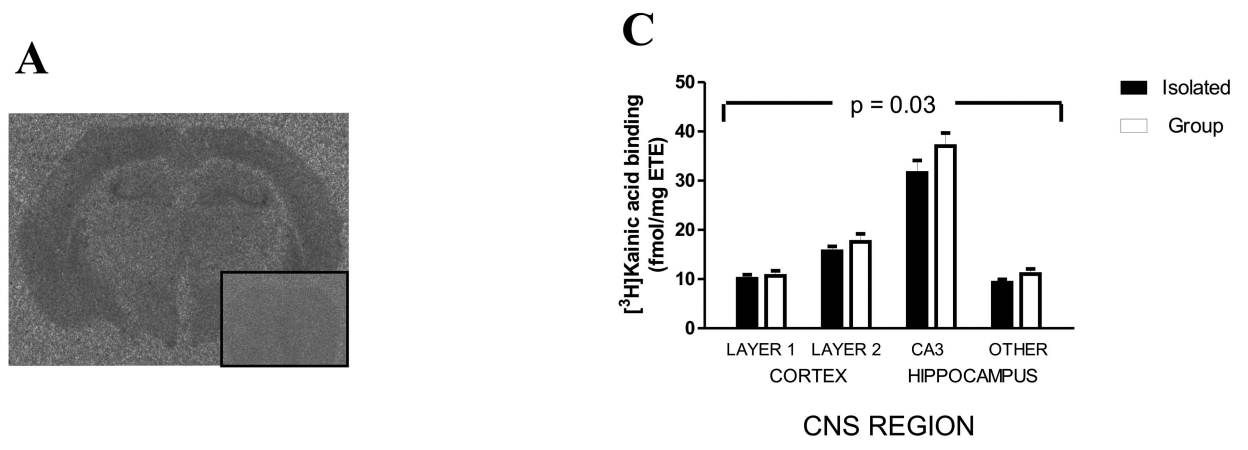

D
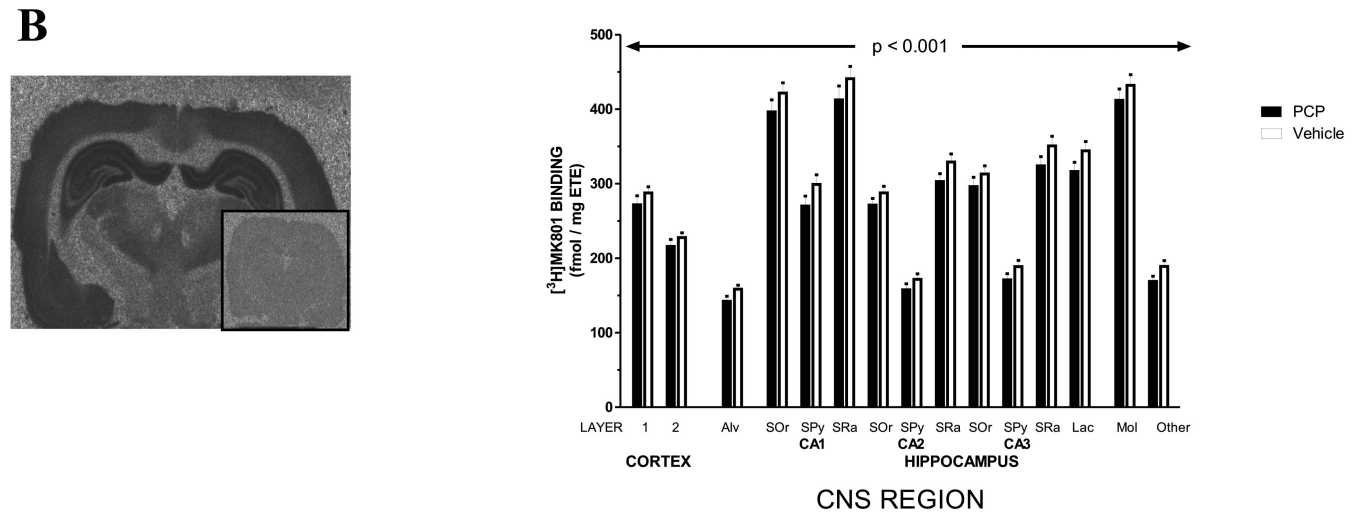

Fig. (2). A \& B: Typical autoradiographs of total and non-specific (Insert) $\left[{ }^{3} \mathrm{H}\right]$ kainate (A) and $\left[{ }^{3} \mathrm{H}\right] \mathrm{MK} 801$ (B) binding to rat CNS. C \& D: The specific binding (mean $\pm \mathrm{SEM}$ ) of $\left[{ }^{3} \mathrm{H}\right]$ kainate to CNS from rats after or combined rearing (C) and $\left[{ }^{3} \mathrm{H}\right] \mathrm{MK} 801 \mathrm{binding}(\mathrm{D})$ to $\mathrm{CNS}$ from rats after sub-chronic PCP treatment

and the Stratum lacunosum which was uniformly labelled through the CA. In the neonatal PCP treated animals, an outlier was detected $\left[{ }^{3} \mathrm{H}\right] \mathrm{MK} 801$ binding for one rat in the alveus of the PCP treated group (Table 2 ) and an outlier was detected in the Stratum moleculare of the dentate gyrus of one rat receiving sub-chronic PCP treatment.

The distribution of data was shown not to be binomial in the CA1 Stratum oriens, CA2 Stratum pyramidale, CA1 Stratum radiatum and Dentate Gyrus Stratum molecular of the group reared rats in the isolated rearing paradigm. In the neonatal PCP treated rats data was not binomially distributed in Layer 1 of the cortex of the PCP treated group. The data from the entire sub-chronic PCP treated paradigm were normally distributed. Thus, because the majority of data was binomially distributed, the more conservative parametric analyses were completed for all comparisons.

\section{I'h]MK 801 Binding: Isolation Reared}

Isolation rearing cause no variation in $\left[{ }^{3} \mathrm{H}\right] \mathrm{MK} 801$ binding with rearing $(\mathrm{F}=0.02$, d.f. $=1,14,299, \mathrm{p}=0.90)$ but there was significant differences between CNS regions $(\mathrm{F}=$ 247 , d.f. $=14,1,299, \mathrm{p}<0.0001)$. There were no interactions between the variables $(\mathrm{F}=0.38$, d.f. $=14,1,299, \mathrm{p}=0.98)$. The rank order of regional binding is shown in was not changed.

\section{['HJMK 801 Binding: Neonatal PCP Treated Rats}

$\left[{ }^{3} \mathrm{H}\right] \mathrm{MK} 801$ binding did not vary after PCP drug treatment $(\mathrm{F}=1.06$, d.f. $=1,14,434, \mathrm{p}=0.31[\mathrm{~F}=0.76$, d.f. $=$ $1,14,435, \mathrm{p}=0.38]$ ) but binding differed significantly between CNS regions $(\mathrm{F}=313$, d.f. $=14,1,434, \mathrm{p}<0.001[\mathrm{~F}$
$=307$, d.f. $=1,14,435, \mathrm{p}<0.001])$. There were no interactions between the variables $(\mathrm{F}=0.26$, d.f. $=14,1,434$, $\mathrm{p}=1.00[\mathrm{~F}=0.27$, d.f. $=1,14,435, \mathrm{p}=1.00])$. The rank order of regional binding was not changed.

\section{H]MK 801 Binding: Sub-Chronic PCP Treated Rats}

$\left[{ }^{3} \mathrm{H}\right]$ MK 801 binding varied after PCP treatment $(\mathrm{F}=$ 23.9, d.f. $=1,14,329, \mathrm{p}<0.001[\mathrm{~F}=24.8$, d.f. $=1,14,330$, $\mathrm{p}$ $<0.001])$ and between CNS regions $(\mathrm{F}=130$, d.f. $=$ $14,1,329, \mathrm{p}<0.001[\mathrm{~F}=130$, d.f. $=14,1,330, \mathrm{p}<0.001])$. There were no interactions between the variables $(\mathrm{F}=0.15$, d.f. $=14,1,330, p=0.99[F=0.13$, d.f. $=14,1,330, p=1.00])$ Post hoc testing failed to identify a significant difference in $\left[{ }^{3} \mathrm{H}\right] \mathrm{MK} 801$ binding with drug treatment and therefore the global difference in radioligand binding was the cumulative effect of non-significant decreases in binding in the subchronic treated group (Table 2, Fig. 2D).

\section{Discussion}

This study has shown that there are widespread decreases in $\left[{ }^{3} \mathrm{H}\right] 4 \mathrm{DAMP}$ binding in the CNS of rats after isolation rearing and sub-chronic PCP treatment. $\left[{ }^{3} \mathrm{H}\right]$ kainate binding showed widespread decreases in rats which had experienced isolated rearing. By contrast, there were widespread increases in $\left[{ }^{3} \mathrm{H}\right] 4 \mathrm{DAMP}$ after neonatal PCP treatment and decreases in $\left[{ }^{3} \mathrm{H}\right] \mathrm{MK} 801$ binding after sub-chronic PCP treatment. $\left[{ }^{3} \mathrm{H}\right]$ pirenzepine binding was not altered in any of the paradigms studied.

Under the assay condition used in this study it has been shown that $\left[{ }^{3} \mathrm{H}\right]$ kainate would predominantly bind to the kainate receptor (KAR) [9], [ $\left.{ }^{3} \mathrm{H}\right] \mathrm{MK} 801$ to NMDAR [9], 
$\left[{ }^{3} \mathrm{H}\right]$ pirenzepine to CHRM1 [60] and $\left[{ }^{3} \mathrm{H}\right] 4 \mathrm{DAMP}$ to CHRM1/CHRM3 [61]. Importantly we have shown changes in $\left[{ }^{3} \mathrm{H}\right]$ 4DAMP binding in the absence of change in $\left[{ }^{3} \mathrm{H}\right]$ pirenzepine binding to CHRM1. This suggests that any changes in $\left[{ }^{3} \mathrm{H}\right]$ 4DAMP binding are reflecting changes in CHRM3.

Based on our current understanding of the binding of radioligands used in our study, our data would be consistent with small widespread decreases in KAR after isolation rearing ranging from $3 \%$ in Layer 1 of the cortex to $15 \%$ in areas of the hippocampus. The data also are consistent with widespread decreases of between 5\% (dentate gyrus stratum molecular) and $11 \%$ (dentate gyrus stratum granulosum + polymorphic layer) in NMDAR after sub-chronic PCP treatment. Decreases in CHRM3 were less than $7 \%$ in the cortex after isolation rearing to between 3.5\% in the Stratum oriens layer 1 and $9.8 \%$ in the polymorphic layer of the dentate gyrus after sub-chronic PCP treatment. Finally, CHRM3 was increased between $1 \%$ in layer 1 of the stratum oriens and $9 \%$ in layer 3 of the stratum radiatum after neonatal PCP treatment. These latter two sets of data suggest that the adult and neonatal PCP treatment paradigms may have subtle effects on the expression of CHRM3 in different CNS regions.

In any study of receptor density, it is important to consider whether the magnitude of change is larger than the receptor reserve, which is the number of receptors present in a tissue in excess of that needed for a full physiological response [62]. This is because any change in receptor density which is smaller than the receptor reserve is unlikely to elicit change in receptor signalling of a magnitude that will have any physiologically significant consequence [63]. In this respect, current data suggest that the NMDAR has a large receptor reserve whereas the other ionotropic glutamate receptors have close to no receptor reserve [64]. This suggests that the decreases in NMDARs we report after subchronic PCP treatment are unlikely to be sufficient to cause a change in receptor signalling. By contrast, the absence of any KAR receptor reserve means that the small change in receptor density we report after isolated rearing would result in altered receptor signalling and therefore could be contributing to the behavioural changes observed in these animals. There is a more comprehensive literature on receptor reserve for CHRM function. Hence, in SH-SY5Y cells it has been reported that the overall receptor reserve for signalling by the CHRM agonist carbachol is 50\% [65]. Studies using cloned receptors in $\mathrm{CHO}$ cells have subsequently suggested that the CHRM3 has a large receptor reserve [66]. In mouse hippocampus, CHRM1 has been reported to have a receptor reserve of $85 \%$ [67] whereas the CHRM2 appears to have little to no receptor reserve [68]. There appears to be little or no receptor reserve for CHRMmediated acetylcholine release [68]. Finally, in the cortex, it has been reported that there is a very low receptor reserve with regards to CHRM1 signalling through phosphoinositide pathways whereas there was a high receptor reserve for CHRM2 signalling through cyclic AMP [69]. Hence, at least with CHRMs, it would appear that receptor reserve can vary significantly depending on the signalling pathway being activated.
The KAR, like other ionotropic glutamate receptors, is made up of sub-units [70] from two families of sub-units (GluR 5, 6 and 7 and KA 1 and 2) which have been differentiated on the basis of gene sequence homologies [71]. Notable for this study is that high affinity $\left[{ }^{3} \mathrm{H}\right]$ kainate binding is to the KA 1 or 2 sub-units [70]. We are not aware of any previous studies examining levels of KAR in the CNS of rats following isolation rearing and therefore our findings of widespread decreases in KAR are novel. It has been reported that 24 hours after a single injection of PCP there is a dose-dependent $(0.86,4.3$ or $8.8 \mathrm{mg} / \mathrm{kg})$ increase in KAR in the Cornu Ammonis 3 and dentate gyrus [72] suggesting drugs which target the NMDAR can indirectly affect the density of KAR. Our data did not show any statistically significant changes in the density of KAR in the CNS of adult rats following neonatal or sub-chronic PCP which could suggest any effects of the PCP treatment on KAR is short lived.

Our finding of global decreases in NMDAR after subchronic PCP treatment is in partial agreement with another study that reported a decrease in that receptor after 7 days administration of MK $801(0.5 \mathrm{mg} / \mathrm{kg})$ to adult rats [73]. In another study it was reported that NMDAR were decreased in 36 day old rats injected with PCP ( $5 \mathrm{mg} / \mathrm{kg}$ ) from PND 5 to 15 [74]; this study also reported decreases in levels of NR2B, but not NR1, NR2A or NR2C, sub-unit mRNA. By contrast, PCP (single injection: $0.86,4.3,8.8 \mathrm{mg} / \mathrm{kg}$ ) has been reported to cause a dose-dependent increase in hippocampal $\left[{ }^{3} \mathrm{H}\right]$ glutamate binding to the NMDAR $24 \mathrm{hr}$ after drug injection [72]. In other studies, using seven day old rats treated with MK $801(1 \mathrm{mg} / \mathrm{kg})$, there was an increase in mRNA for the NR1, NR2A, NR2B and NR2D NMDAR sub-units in the cortex, hippocampus and striatum 2 to 4 hours after the administration of MK801 [52, 75]. Thus it would seem that the effects of NMDAR antagonists on NMDAR levels may depend on the age of the rats and dosing regimen. This notion is supported by a study that compared the outcome of a single dose of PCP $(10 \mathrm{mg} / \mathrm{kg})$ on PN7 (rats sacrificed after $0,4,8$ or $24 \mathrm{hr}$ ) to that of multiple injections of the same does of PCP on PND 7, 9 and 11 (rats sacrificed after $24 \mathrm{hr}$ ) [76]. The single injection of PCP increased the levels of cortical NR1 and NR2B, but not NR2A, sub-units of the NMDAR whereas repeated PCP injections increased cortical NR1 and NR2A, but not NR2B, sub-units of the NMDAR. Our study has shown that repeated injection of PCP during the neonatal period does not change levels of NMDAR in the adult CNS suggesting any effects of injecting PCP on NMDAR density is not long lasting.

This study has shown there are small widespread changes in levels of CHRM3 following isolation rearing $(<-7.5 \%)$, neonatal PCP administration (1 to 9\%) and sub-chronic PCP treatment (4 to 10\%). However, none of these changes in CHRM3 exceed the CHRM3 receptor reserve and thus are unlikely to be of a sufficient magnitude to have significant physiological outcomes. This hypothesis needs to be treated with some caution as it has been shown that apparent receptor reserves differ for different CHRM / signalling pathway interactions and thus it may be premature to totally exclude the possibility that such small changes in CHRM3 density are having effects on signalling pathways and hence cellular function. In this study, there was no change in 
$\left[{ }^{3} \mathrm{H}\right]$ pirenzepine binding in any paradigm which differs from a previous study that showed complex changes in $\left[{ }^{3} \mathrm{H}\right]$ pirenzepine following neonatal PCP treatment, culminating in a $10 \%$ increase in binding in the cortex of adult rats after drug treatment [77].

In conclusion, this study shows that animal models developed to study the pathophysiology of schizophrenia cause differential changes in the molecular cytoarchitecture of the CNS. However, neither isolation rearing nor PCP treatment caused changes in the molecular cytoarchitecture of the CNS in rodent that have been reported in the CNS of subjects with schizophrenia. Significantly, ongoing studies of the CNS from subjects with schizophrenia are revealing that extensive changes in gene expression are associated with the disorder [78] and it is therefore likely that changes in the expression of some of these genes will occur in different animal models of the disorder. The challenge will therefore be to identify an animal model that has a change in CNS expression of a specific gene which mirrors what occurs in the CNS from subjects with schizophrenia. For example, our data shows a decrease in KAR after isolation rearing and some studies report decrease in KAR in schizophrenia [6, 9, $79,80]$. Hence, further study of KAR in rats following isolation rearing should allow a greater understanding as to how exposure to such an environmental factor earlier in life can cause changes in the expression of a gene similar to those observed in subjects with schizophrenia.

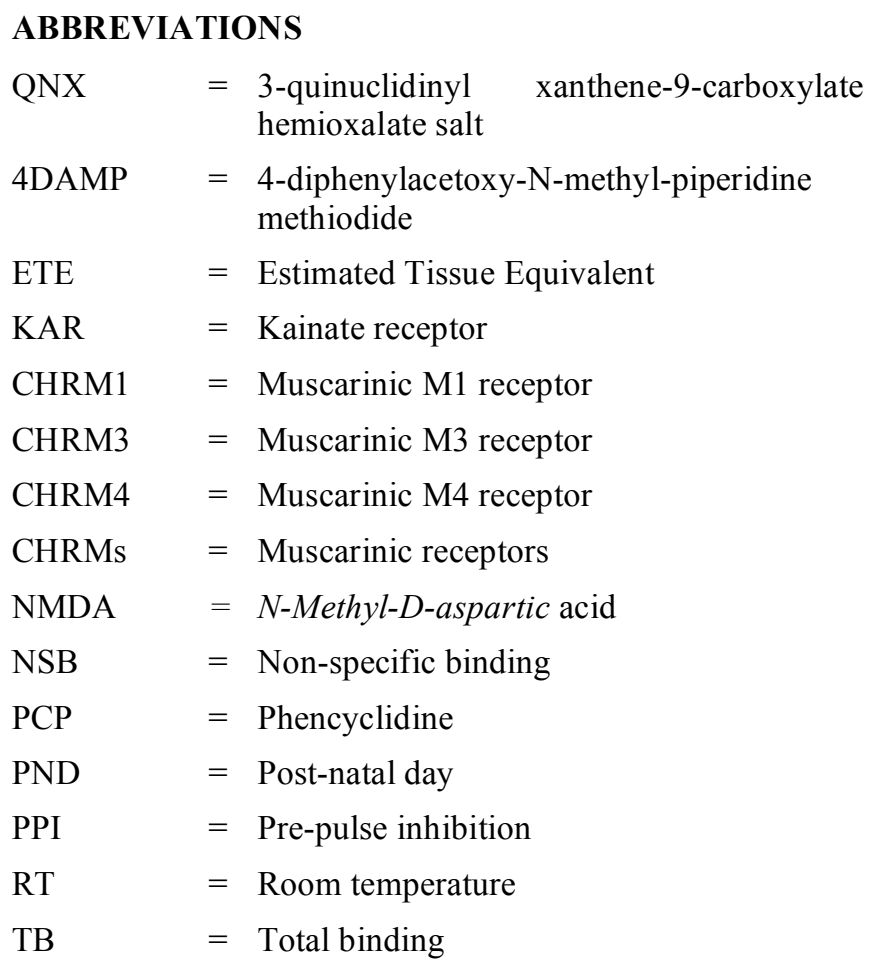

\section{ACKNOWLEDGEMENTS}

BD is an NH\&MRC Senior Research Fellow (APP1002240) and ES is the ARH Royce Abbey PostDoctoral Fellow. This research was supported in part by NHMRC Project grants 509333, 628669 and 566967. The study was supported by Operational Infrastructure Support (OIS) from the Victorian State Government and by the funding grants.

\section{CONFLICTS OF INTEREST STATEMENT}

The authors declare no conflict of interest.

\section{REFERENCES}

[1] Tsuang M. Schizophrenia: genes and environment. Biol Psychiatry 2000; 47: 210-20.

[2] Rapoport JL, Addington AM, Rangou S, Psych MR. The neurodevelopmental model of schizophrenia: update 2005. Mol Psychiatry 2005; 10: 434-49.

[3] Loranger AW. Sex difference in age at onset of schizophrenia Arch Gen Psychiatry 1984; 41: 157-61.

[4] Feinberg, I. Schizophrenia: caused by a fault in programmed synaptic elimination during adolescence? J Psychiatr Res 1982; 17: 319-37.

[5] Dean B. Is schizophrenia the price of human central nervous system complexity? Aust NZJ Psychiatry 2009; 43: 13-24.

[6] Kerwin RW, Patel S, Meldrum BS, Czudek C, Reynolds GP. Asymmetrical loss of glutamate receptor subtype in left hippocampus in schizophrenia. Lancet 1988; 1: 583-84.

[7] Dean B, Crook JM, Opeskin K, Hill C, Keks N, Copolov DL. The density of muscarinic M1 receptors is decreased in the caudateputamen of subjects with schizophrenia. Mol Psychiatry 1996; 1: 54-8.

[8] Dracheva S, McGurk SR, Haroutunian V. mRNA expression of AMPA receptors and AMPA receptor binding proteins in the cerebral cortex of elderly schizophrenics. J Neurosci Res 2005; 79: 868-78.

[9] Scarr E, Beneyto M, Meador-Woodruff JH, Deans B. Cortical glutamatergic markers in schizophrenia. Neuropsychopharmacology 2005; 30: 1521-31.

[10] Beneyto M, Kristiansen LV, Oni-Orisan A, McCullumsmith RE, Meador-Woodruff JH. Abnormal glutamate receptor expression in the medial temporal lobe in schizophrenia and mood disorders. Neuropsychopharmacology 2007; 32: 1888-902.

[11] Beneyto M, Meador-Woodruff JH. Lamina-specific abnormalities of NMDA receptor-associated postsynaptic protein transcripts in the prefrontal cortex in schizophrenia and bipolar disorder. Neuropsychopharmacology 2008; 33: 2175-86.

[12] Sokolov BP. Expression of NMDAR1, GluR1, GluR7, and KA1 glutamate receptor mRNAs is decreased in frontal cortex of "neuroleptic-free" schizophrenics: evidence on reversible upregulation by typical neuroleptics. J Neurochem 1998; 71: 2454-64.

[13] Newell KA, Zavitsanou K, Huang XF. Ionotropic glutamate receptor binding in the posterior cingulate cortex in schizophrenia patients. Neuroreport 2005; 16: 1363-67.

[14] Crook JM, Dean B, Pavey G, Copolov D. The binding of [3H]AFDX 384 is reduced in the caudate-putamen of subjects with schizophrenia. Life Sci 1999; 64: 1761-71.

[15] Crook JM, Tomaskovic-Crook E, Copolov DL, Dean B. Decreased muscarinic receptor binding in subjects with schizophrenia: a study of the human hippocampal formation. Biol Psychiatry 2000; 48: 381-8.

[16] Dean B, Crook JM, Pavey G, Opeskin K, Copolov DL. Muscarinic 1 and 2 receptor mRNA in the human caudate-putamen: no change in m1 mRNA in schizophrenia. Mol Psychiatry 2000; 5: 203-7.

[17] Crook JM, Tomaskovic-Crook E, Copolov DL, Dean B. Low muscarinic receptor binding in prefrontal cortex from subjects with schizophrenia: a study of Brodmann's areas 8, 9, 10, and 46 and the effects of neuroleptic drug treatment. Am J Psychiatry 2001; 158: 918-25.

[18] Dean B, McLeod M, Keriakous D, McKenzie J, Scarr E. Decreased muscarinic1 receptors in the dorsolateral prefrontal cortex of subjects with schizophrenia. Mol Psychiatry 2002; 7: 1083-91.

[19] Zavitsanou K, Katsifis A, Mattner F, Huang XF. Investigation of $\mathrm{m} 1 / \mathrm{m} 4$ muscarinic receptors in the anterior cingulate cortex in schizophrenia, bipolar disorder, and major depression disorder. Neuropsychopharmacology 2004; 29: 619-25.

[20] Scarr E, Sundram S, Keriakous D, Dean B. Altered hippocampal muscarinic M4, but not M1, receptor expression from subjects with schizophrenia. Biol Psychiatry 2007; 61: 1161-70.

[21] Mancama D, Arranz MJ, Landau S, Kerwin R. Reduced expression of the muscarinic 1 receptor cortical subtype in schizophrenia. Am J Med Genet. B Neuropsychiatr Genet 2003; 119B: 2-6. 
[22] Newell KA, Zavitsanou K, Jew SK, Huang XF. Alterations of muscarinic and GABA receptor binding in the posterior cingulate cortex in schizophrenia. Prog Neuropsychopharmacol Biol Psychiatry 2007; 31: 225-33.

[23] Restivo L, Ferrari F, Passino E, et al Ammassari-Teule, M. Enriched environment promotes behavioral and morphological recovery in a mouse model for the fragile $\mathrm{X}$ syndrome. Proc Natl Acad Sci USA 2005; 102: 11557-62.

[24] McOmish CE, Burrows E, Howard M, et al. Phospholipase C-beta1 knockout mice exhibit endophenotypes modeling schizophrenia which are rescued by environmental enrichment and clozapine administration. Mol Psychiatry 2008; 13: 661-72.

[25] Javitt, DC, Zukin SR. Recent advances in the phencyclidine model of schizophrenia. Am J Psychiatry 1991; 148: 1301-8.

[26] Dean B. Signal transmission, rather than reception, is the underlying neurochemical abnormality in schizophrenia. Aust NZJ Psychiatry 2000; 34: 560-9.

[27] Coyle JT. Glutamate and schizophrenia: beyond the dopamine hypothesis. Cell Mol Neurobiol 2006; 26: 365-84.

[28] Steinpreis RE. The behavioral and neurochemical effects of phencyclidine in humans and animals: some implications for modeling psychosis. Behav Brain Res 1996; 74: 45-55.

[29] Mouri A, Noda Y, Enomoto T, Nabeshima T. Phencyclidine animal models of schizophrenia: approaches from abnormality of glutamatergic neurotransmission and neurodevelopment. Neurochem Int 2007; 51: 173-84.

[30] Jentsch JD, Tran A, Le D, Youngren KD, Roth, RH. Subchronic phencyclidine administration reduces mesoprefrontal dopamine utilization and impairs prefrontal cortical-dependent cognition in the rat. Neuropsychopharmacology 1997; 17: 92-9.

[31] Wang C, McInnis J, Ross-Sanchez M, Shinnick-Gallagher P, Wiley JL, Johnson KM. Long-term behavioral and neurodegenerative effects of perinatal phencyclidine administration: implications for schizophrenia. Neuroscience 2001; 107: 535-50.

[32] Olney JW, Newcomer JW, Farber NB. NMDA receptor hypofunction model of schizophrenia. J Psychiatr Res 1999; 33: 523-33.

[33] Arnold SE. Neurodevelopmental abnormalities in schizophrenia: insights from neuropathology. Dev Psychopathol 1999; 11: 439-56.

[34] Broberg BV, Glenthoj BY, Dias R, Larsen DB, Olsen CK. Reversal of cognitive deficits by an ampakine (CX516) and sertindole in two animal models of schizophrenia--sub-chronic and early postnatal PCP treatment in attentional set-shifting. Psychopharmacology (Berl) 2009; 206: 631-40

[35] Grayson B, Idris NF, Neil, JC. Atypical antipsychotics attenuate a sub-chronic PCP-induced cognitive deficit in the novel object recognition task in the rat. Behav Brain Res 2007; 184: 31-8.

[36] Jentsch, JD, Taylor, JR, Roth, RH. Subchronic phencyclidine administration increases mesolimbic dopaminergic system responsivity and augments stress- and psychostimulant-induced hyperlocomotion. Neuropsychopharmacology 1998; 19: 105-13.

[37] Lee PR, Brady DL, Shapiro RA, Dorsa DM, Koenig JI. Social interaction deficits caused by chronic phencyclidine administration are reversed by oxytocin. Neuropsychopharmacology 2005; 30: 1883-94.

[38] Snigdha S, Neill JC. Efficacy of antipsychotics to reverse phencyclidine-induced social interaction deficits in female rats--a preliminary investigation. Behav Brain Res 2008; 187: 489-94.

[39] Harich S, Gross G, Bespalov A. Stimulation of the metabotropic glutamate $2 / 3$ receptor attenuates social novelty discrimination deficits induced by neonatal phencyclidine treatment. Psychopharmacology (Berl) 2007; 192: 511-9.

[40] Abdul-Monim Z, Neill JC, Reynolds GP. Sub-chronic psychotomimetic phencyclidine induces deficits in reversal learning and alterations in parvalbumin-immunoreactive expression in the rat. J Psychopharmacol 2007; 21: 198-205.

[41] Wang CZ, Yang SF, Xia Y, Johnson KM. Postnatal phencyclidine administration selectively reduces adult cortical parvalbumincontaining interneurons. Neuropsychopharmacology 2008; 33: 2442-55.

[42] Reynolds GP, Abdul-Monim Z, Neill JC, Zhang ZJ. Calcium binding protein markers of GABA deficits in schizophrenia-postmortem studies and animal models. Neurotox Res 2004; 6: 57 61

[43] Harte MK, Powell SB, Swerdlow NR, Geyer MA, Reynolds GP. Deficits in parvalbumin and calbindin immunoreactive cells in the hippocampus of isolation reared rats. J.Neural Transm 2007; 114: 893-8.

[44] Leng A, Feldo, J, Ferge, B. Long-term social isolation and medial prefrontal cortex: dopaminergic and cholinergic neurotransmission. Pharmacol Biochem Behav 2004; 77: 371-9.

[45] Cilia J, Reavill C, Hagan JJ, Jones DN. Long-term evaluation of isolation-rearing induced prepulse inhibition deficits in rats. Psychopharmacology (Berl) 2001; 156: 327-37.

[46] Day-Wilson KM, Jones DN, Southam E, Cilia J, Totterdell S Medial prefrontal cortex volume loss in rats with isolation rearinginduced deficits in prepulse inhibition of acoustic startle. Neuroscience 2006; 141: 1113-21.

[47] Bloomfield C, French SJ, Jones DN, et al. Chandelier cartridges in the prefrontal cortex are reduced in isolation reared rats. Synapse 2008; 62: 628-31.

[48] Turnock-Jones JJ, Jennings CA, Robbins MJ et al . Increased expression of the NR2A NMDA receptor subunit in the prefrontal cortex of rats reared in isolation. Synapse 2009; 63: 836-46.

[49] Harris LW, Sharp T, Gartlon J, Jones DN, Harrison PJ. Long-term behavioural, molecular and morphological effects of neonatal NMDA receptor antagonism. Eur J Neurosci 2003; 18: 1706-10.

[50] Gartlon J, Harte MK, Reynolds GP, Jones DN. PCP administration to neonatal rats results in long-term deficits in novel object recognition and reduced parvalbumin-immunoreactive neurons in the hippocampus. J Psychopharmacol 2007; 21: A66.

[51] Cilia J, Cluderay JE, Robbins MJ, et al. Reversal of isolationrearing-induced PPI deficits by an alpha7 nicotinic receptor agonist. Psychopharmacology (Berl) 2005; 182: 214-9.

[52] Wiseman Harris L, Sharp T, Gartlon J, Jones DN, Harrison PJ. Long-term behavioural, molecular and morphological effects of neonatal NMDA receptor antagonism. Eur J Neurosci 2003; 18: 1706-10.

[53] Kalinichev M, Robbins MJ, Hartfield EM, et al .Comparison between intraperitoneal and subcutaneous phencyclidine administration in Sprague-Dawley rats: a locomotor activity and gene induction study. Prog Neuropsychopharmacol Biol Psychiatry 2008; 32: 414-22.

[54] Scarr E, Pavey G, Sundram S, MacKinnon A, Dean B. Decreased hippocampal NMDA, but not kainate or AMPA receptors in bipolar disorder. Bipolar Disord 2003; 5: 257-64.

[55] Gibbons AS, Scarr E, McLean C, Sundram S, Dean B. Decreased muscarinic receptor binding in the frontal cortex of bipolar disorder and major depressive disorder subjects. J Affect Disord 2009; 116 : 184-91.

[56] Pavey GM, Copolov DL, Dean B. High-resolution phosphor imaging: validation for use with human brain tissue sections to determine the affinity and density of radioligand binding. J Neurosci Methods 2002; 116: 157-63.

[57] Dean B, Soulby A, Evin GM, Scarr E. Levels of [(3)H]pirenzepine binding in Brodmann's area 6 from subjects with schizophrenia is not associated with changes in the transcription factor SP1 or BACE1. Schizophr Res 2008; 106: 229-36.

[58] Jenkins, SH. Data pooling and type 1 errors. Anim Behav 2002; 63: F9-F11.

[59] Zilles K, Qu MS, Schroder H, Schleicher A. Neurotransmitter receptors and cortical architecture. J Hirnforsch 1991; 32: 343-56.

[60] Scarr, E, Dean, B. Muscarinic receptors: do they have a role in the pathology and treatment of schizophrenia? J Neurochem 2008; 107: 1188-95.

[61] Araujo DM, Lapchak PA, Quirion R. Heterogeneous binding of $[3 \mathrm{H}] 4-\mathrm{DAMP}$ to muscarinic cholinergic sites in the rat brain evidence from membrane binding and autoradiographic studies. Synapse 1991; 9: 165-76.

[62] Stephenson RP. A modification of receptor theory. Br J Pharmacol Chemother 1956; 11: 379-93.

[63] Krudewig, R, Langer, B, Vogler, O, et al. Distinct internalization of M2 muscarinic acetylcholine receptors confers selective and long-lasting desensitization of signaling to phospholipase C. J Neurochem 2000; 74: 1721-30.

[64] Martin D, Bowe MA, Nadler JV. A grease-gap method for studying the excitatory amino acid pharmacology of CA1 hippocampal pyramidal cells. J Neurosci Methods 1989; 29: 107-14.

[65] Szekeres PG, Koenig JA, Edwardson JM. Involvement of receptor cycling and receptor reserve in resensitization of muscarinic responses in SH-SY5Y human neuroblastoma cells J Neurochem 1998; 70: 1694-703. 
[66] Wood MD, Murkitt KL, Ho M, et al. Functional comparison of muscarinic partial agonists at muscarinic receptor subtypes hM1, hM2, hM3, hM4 and hM5 using microphysiometry. Br J Pharmacol 1999; 126: 1620-4.

[67] Porter AC, Bymaster FP, DeLapp NW, et al. M1 muscarinic receptor signaling in mouse hippocampus and cortex. Brain Res 2002; 944: 82-9.

[68] Vickroy TW, Malphurs WL, Defiebre NC. Absence of receptor reserve at hippocampal muscarinic autoreceptors which inhibit stimulus-dependent acetylcholine release. J Pharmacol Exp Ther 1993; 267: 1198-204.

[69] McKinney M, Anderson D, Vella-Rountree L. Different agonistreceptor active conformations for rat brain $\mathrm{M} 1$ and $\mathrm{M} 2$ muscarinic receptors that are separately coupled to two biochemical effector systems. Mol Pharmacol 1989; 35: 39-47.

[70] Chittajallu R, Braithwaite SP, Clarke VR, Henley JM. Kainate receptors: subunits, synaptic localization and function. Trends Pharmacol Sci 1999; 20: 26-35.

[71] Wollmuth LP, Sobolevsky AI. Structure and gating of the glutamate receptor ion channel. Trends Neurosci 2004; 27: 321-8.

[72] Gao XM,Tamminga CA. An increase in NMDA-sensitive $[3 \mathrm{H}]$ glutamate and $[3 \mathrm{H}] \mathrm{kainate}$ binding in hippocampus 24 hours after PCP. Neurosci Lett 1994; 174: 149-53.

[73] Manallack DT, Lodge D, Beart PM. Subchronic administration of MK-801 in the rat decreases cortical binding of [3H]D-AP5, suggesting down-regulation of the cortical N-methyl-D-aspartate receptors. Neuroscience 1989; 30: 87-94.
[74] Sircar R, Follesa P, Ticku MK. Postnatal phencyclidine treatment differentially regulates $\mathrm{N}$-methyl-D-aspartate receptor subunit mRNA expression in developing rat cerebral cortex. Brain Res Mol Brain Res 1996; 40: 214-20.

[75] Wilson MA, Kinsman SL, Johnston MV. Expression of NMDA receptor subunit mRNA after MK-801 treatment in neonatal rats. Brain Res Dev Brain Res 1998; 109: 211-20.

[76] Anastasio NC, Johnson KM. Differential regulation of the NMDA receptor by acute and sub-chronic phencyclidine administration in the developing rat. J Neurochem 2008; 104: 1210-8.

[77] du Bois TM, Newell KA, Han M, Deng C, Huang XF. Perinatal PCP treatment alters the developmental expression of prefrontal and hippocampal muscarinic receptors. Prog Neuropsychopharmacol Biol Psychiatry 2009; 33: 37-40.

[78] Dean B, Keriakous D, Scarr E, Thomas EA. Understanding the pathology of schizophrenia: The impact of high-throughput screening of the genome and proteome in postmortem CNS. Curr Rev Psychiatr 2005; 1: 1-9.

[79] Meador-Woodruff JH, Davis KL, Haroutunian V. Abnormal kainate receptor expression in prefrontal cortex in schizophrenia. Neuropsychopharmacology 2001; 24: 545-52.

[80] Kerwin R, Patel S, Meldrum B. Quantitative autoradiographic analysis of glutamate binding sites in the hippocampal formation in normal and schizophrenic brain post mortem. Neuroscience 1990; 39: 25-32.

(C) Dean et al.; Licensee Bentham Open.

This is an open access article licensed under the terms of the Creative Commons Attribution Non-Commercial License (http://creativecommons.org/licenses/by-nc/3.0/) which permits unrestricted, non-commercial use, distribution and reproduction in any medium, provided the work is properly cited. 